\title{
RELATIONS AND EVOLUTION IN CHEILANTHES (SINOPTERIDACEAE, PTERIDOPHYTA) IN MACARONESIA AND MEDITERRANEAN AREA, DEDUCED FROM GENOME ANALYSIS OF THEIR HYBRIDS
}

\author{
G. VIDA, A. MAJOR \& T. REICHSTEIN
}

\begin{abstract}
: Nine species of "Cheilantoid ferns" are known to grow in Macaronesia and the Mediterranean basin. Two of them (lacking a pseudo-indusium and having the basic chromosome number $X=29$ ), both aggregate species which we prefer to retain in Notholaena, are not included in this study. The other seven species (with distinct pseudo-indusium and the basic chromosome number $\mathrm{X}=30$ ), which we accept as members of the genus Cheilanthes Sw. sensu stricto, were subjected to detailed genome analysis of their natural and experimentally produced hybrids and shown to represent an aggregate of four very distinct ancestral diploids and three allotetraploids. The latter must have once been formed by chromosome doubling in the three diploid hybrids of $\mathbf{C}$. maderensis Lowe with the other three diploid species. Theoretically three more allotetraploids would be possible but their formation has obviously been prevented by the geographical separation of the three respective diploids. The most widely distributed of the tetraploids, i.e. C. pteridioides (Reich.) C.Chr. has also been resynthesized from its ancestors (still sympatric) under experimental conditions. The intermediate morphology of the allotetraploids (as compared with their diploid ancestors) is obviously the reason why their status and existence has so long escaped recognition in Europe. These seven species form a natural group and, in our opinion, should not be divided into sections.
\end{abstract}

RESUMEN: Se conocen nueve especies de "helechos Cheilantoides" que viven en Macaronesia y la cuenca Mediterranea. Dos de ellos, (sin pseudoindusio y con número cromosómico básico $\mathrm{X}=29$ ) que preferimos incluir en Notholaena, no se estudian en este trabajo. Las otras siete especies (con pseudoindusio y número cromosómico básico $\mathrm{X}=30$ ) que reconocemos como miembros del género Cheilanthes Sw. sensu stricto, fueron objeto de un análisis detallado del genoma de sus híbridos, tanto de los naturales, como de los producidos experimentalmente mostrando un agregado de cuatro ancestrales diploides muy distintos y tres alotetraploides. Estos últimos deben haberse formado por duplicación de los cromosomas en los tres híbridos diploides resultantes del cruzamiento de C. maderensis con las otras tres especies diploides. Teóricamente son posibles otros tres alotetraploides, pero su formación se ha impedido por la separación geográfica de los 3 diploides respectivos. 
Los tetraploides más ampliamente distribuidos, como por ejemplo Cheilanthes pteridioides (Reich.) C. Chr., han sido igualmente resintetizados a partir de sus ancestros bajo condiciones experimentales. La morfología intermedia de los alotetraploides (comparada con sus ancestros diploides) es obviamente la razón por la que su existencia y status han pasado inadvertidos en Europa. Estas siete especies forman un grupo natural que, en nuestra opinión, no debe ser dividido en secciones.

\section{INTRODUCTION}

When studying the taxonomy of the genus Cheilanthes Swartz (1806) in Europe (Vida et al. 1971; Nardi et al. 1978; 1979) it soon became apparent, that two things were indispensable for proper understanding of the status, relationship, distribution and possible evolution of its members. These are: 1. Inclusion of Macaronesia (particularly the Canary Islands) in the area of investigation, because one important ancestor, C. pulchella, is endemic there. 2. Experimental work with cytology, hybridization and detailed genome analysis in the hybrids, using methods introduced by I. Manton (1950), and so successfully applied to Asplenium, Dryopteris, Polystichum and some other fern genera by J. Bouharmont, A.F. Braithwaite, G. Brownlie, P.J. Brownsey, J.I. Emmott, M. Gibby, J.D. Lovis, M.G. Shivas, A. Sleep, G. Vida, D. Wagner, W.H. Wagner, S. Walker, I'.G. Walker and other workers, see reviews in Lovis $(1968,1973,1975,1977)$ and T.G. Walker (1979).

In this study we describe the genome analysis of three natural and nine experimentally produced hybrids of seven species (No. 39 of table 1), which form a natural group. Some of the results (without documentation) have been briefly quoted already (Vida et al. 1971, Nardi et al. 1978) and precise chromosome numbers of the species (with documentation) have been reported (Vida et al. 1971).

\subsection{RECOGNIZED TAXA}

When Flora Europaea (Vol. I 1964) appeared, Jermy \& Fuchs could quote only five species of Cheilanthes sensu lato (including Notholaena) for Europe. At this time it was hardly possible to make revisions in herbaria, because many specimens could not be properly identified. After accepting $C$. maderensis at specific rank (Vida et al. 1971), rediscovery of C. tinaei Tod. (sub C. corsica Reichst. et Vida 1973, see Nardi et al. 1978, 1979) for Europe, N-Africa and Turkey, recently also for Madeira and Tenerife (H. \& K. Rasbach \& Reichstein in preparation) and discovery of C. guanchica Bolle for Europe and N-Africa (Rasbach et Reichstein 1977, Nardi et al. 1978, 1979), there is some reason to assume that all existing members in the area are known. This gave the necessary basis for revision of existing collections in herbaria (Nardi et al. 1978, 1979; Sáenz de Rivas \& Rivas-Martinez 1979; Badré \& Deschatres 1979; others have still to be done). Table 1 lists the nine species (including two sub-specific taxa)growing in the Macaronesian Islands and in Europe. 
1. Notholaena marantae (L.) Desv. = Cheilanthes marantae (L.) Domin in two subspecies, botr so far always found diploid, $\mathrm{n}=29,2 \mathrm{n}=58$.

a. ssp. marantae Distr.: through the whole range, except Macaronesia, i.e. S- and Middle-Europe, N-Africa, W-Asia to Himalayas.

b. ssp. subcordata (Cav.) Kunkel (1969). Distr.: mainly in Macaronesia (Canary Islands, Madeira, Cap Verdes) also reported (rare) from Portugal and Spain.

2. Notholaena lanuginosa (Desf.) Desv. ex Poiret = Cheilanthes vellea (Ait.) F.v. Muell., Known in two cytotypes.

a. Diploid cytotype, $n=29,2 n=58$. Distr.: Canary Islands, Spain (rare);

b. Tetraploid cytotype, $\mathrm{n}=58,2 \mathrm{n}=116$. Distr.: (as far known) through the whole range: Macaronesia, S-Europe, N-Africa, Asia to W-Himalayas.

3. C. hispanica Mett. diploid, $\mathrm{n}=30,2 \mathrm{n}=60$. Distr. Portugal, Spain, SW-France, NW-Africa.

4. C. maderensis Lowe, diploid, $\mathrm{n}=30,2 \mathrm{n}=60$. Distr. Macaronesia, SW-Europe (reaching Italy), NW-Africa.

5. C. persica (Bory) Mett. ex Kuhn, diploid, $\mathrm{n}=30,2 \mathrm{n}=60$. Distr.: SE-Europe (from Italy eastward), N-Africa (doubtful) to W-Himalayas.

6. C. pulchella Bory ex Willd., diploid, $\mathrm{n}=30,2 \mathrm{n}=60$. Endemic to Canary Islands.

7. C. guanchica Bolle, tetraploid, $n=60,2 n=120$. Distr. Canary Islands, SW-Europe and NW-Africa.

8. C. pteridioides (Reich.) C. Chr. = C. fragrans (L. fil.) Swartz, tetraploid, $\mathrm{n}=60,2 \mathrm{n}=120$. Distr.: Cap Verdes Islands, S-Europe, N-Africa, W-Asia to Himalayas.

9. C. tinaei Tod. = C. corsica Reichst. et Vida, tetraploid, $\mathrm{n}=60,2 \mathrm{n}=120$. Distr.: Madeira (rare). Tenerife, SW-Europe, N-Africa, Turkey.

Table 1. The eleven taxa of "Cheilantoid ferns" (nine species and two representatives of subspecific rank) growing in the Macaronesian Islands, Europe, N-Africa and W-Asia). Other synonyms see Nardi et al. (1979).

\subsection{NOMENCLATURE}

The two cytotypes of Notholaena lanuginosa have not yet been given a valid name, because the ploidy level of the type (= ssp. lanuginosa), based on Acrostichum lanuginosum Desf. from N-Africa is still unknown. If this taxon is treated as Cheilanthes vellea, based on Acrostichum velleum Aiton from Madeira, the tetraploid cytotype would have to be ssp. vellea because only the tetraploid is known to grow in Madeira (Vida et al. 1971).

The first two taxa ( 1 and 2 ) of table 1, both aggregate spe- 
cies, deserve special status and in nearly all European floras edited before 1964 (the year of publication of Tutin et al. Flora Europaea I), e.g. Willkomm et Lange (1870), Coste (1906), Fiori (1923; 1943), Dalla Torre \& Sarntheim (1906), Fritsch (1897), Janchen (1956) and others, have been placed in a separate genus Notholaena $\mathrm{R} . \mathrm{Br}$. and Notholaena marantae accepted as type of Notholaena by Maxon (1926), Tryon (1956) and Pichi-Sermolli (1977). Notholaena was, however, treated as synonym of Cheilanthes already by Mettenius (1859), Domin (1913), Copeland (1947), Fuchs (1961), Jermy \& Fuchs (1964, in Tutin et al. Flora Europaea I) and some authors of other florae since, e.g. Vasconcellos (1968), Amaral Franco (1971), Guinochet \& Vilmorin (1973), Mickel (1979), but maintained by Pichi-Sermolli (1977), de la Sota (1977) and others.

Inclusion of Notholaena into the genus Cheilanthes s.l. in recent years (since 1964) was mainly provoked by the statements of Fuchs (1961: 39), saying that Notholaena marantae has a distinct pseudo-indusium in the juvenile stage and therefore belongs to Cheilanthes in the strictest sense of the word. We do not agree with this statement which may be based on examination of inadequate herbarium material.

We have raised all the taxa of table 1 (except C. hispanica) from spores and were able to study their development as living plants at all stages. We have found that all the seven members of Cheilanthes s.str. (No. 3-9 of table 1) have no pseudo-indusium when young (first 2-3 leaves) and develop this structure only during maturation. Neither Notholaena marantae nor N. lanuginosa produce a pseudo-indusium (= reflexed modified leaf margin) at any stage, neither when young nor mature. We also do not agree with the statement (Fuchs 1961: 39) that in Notholaena the original former under-side of the leaf becomes the upper side during maturation. We therefore prefer to follow Pichi-Sermolli (1977) and treat these two species sub Notholaena with $\mathbf{N}$. marantae as lectotype of the genus.

We agree that Notholaena marantae and $C$. vellea are probably less closely related to each other than the seven further members of the list (see below). Nevertheless, they have some features in common, mainly the lack of (or at best presence of a rudimentary) pseudo-indusium and the basic chromosome number $X=29$. Together with a few other particularities this is a good reason to accept them as members of a separate genus Notholaena. But even if separating them on lower level (subgenus or section) within the genus Cheilanthes sensu lato, they should be clearly separated from the seven other taxa (No. 3-9 of table 1). As pointed out by Nardi et al. (1978) such a splitting of the genus Cheilanthes should await monographic treatment on world-wide basis and further experimental hybridization work. Meanwhile Sáenz de Rivas \& Rivas-Martínez (1979), in an extensive study on spore ornamentation, in which they also treat Notholaena as a synonym of Cheilanthes, have suggested placing $C$. vellea in a monotypic subgenus Cosentina; this may be justified but needs further study. The remaining Spanish taxa (including C. marantae) they unite in the subgenus Cheilanthes with three sections: I Cheilanthes, II Hispanica and III Marantae. This is not justified in our opinion. But as we have not included C. marantae nor C. vellea in our hybridization programme, we refrain from discussing their possible relationship, and we still consider it premature to suggest a suitable classification.

The other seven species, No. 3-9 of table 1, which possess a distinct pseudo-indusium, a basic chromosome number $X=30$ and a 
few other characters in common, form a natural group and we see no reason to divide them further into sections. The results of hybridization clearly support this conclusion. The group of all these seven species may deserve to be recognized as one section (or other subgeneric unit) within the genus Cheilanthes, perhaps together with some other species from other continents (particularly Africa), but not including C. marantae.

\section{MATERIAL AND METHODS}

Precise origin of plants and spores for raising progeny and for hybridization are given in the appendix. Raising plants from spores in Basel (TR) was done on Agar medium sterilized only 2030 minutes at $100^{\circ}$ in Erlenmeyer flasks, tightly closed with plastic after sowing and kept in nearly full sunlight, transplanting the prothalli (when c. 1-2 mm high after 2-5 months) on soil (see Reichstein et al. 1973) and then keeping them moist and partly shaded, occasionally bathing the pots in boiled and cooled tap water, just to the rim for two days in sunlight; in Budapest (GV and AM) sowing was made directly on soil as described by Lovis (1968). Spores were collected by preserving ripe fronds as clean as possible in clean paper (flimsies) and dried in the press. Spores were used without sterilization, very rarely infections (algae or moulds) occured. Young sporophytes were planted individually in pots, kept out of doors in summer in full sun or partly shaded and in the cold greenhouse (minimal temperature $+2{ }^{\circ} \mathrm{C}$ ) in winter. Particular attention was devoted to prevent infection by parasitic nematodes ("eal worms") by sterilizing pots, soil etc. in steam. Aphids were controlled by fumigation. Watering of prothallia on soil and baby sporophytes was done with boiled and cooled tap water, bigger plants with tap water directly. All species except $C$. hispanica grew well to full maturity (reaching after 1-2 years), although C. pulchella, C. guanchica and C. tinaei often succumbed when $2-4$ years old, while C. maderensis, C. persica and C. pteridioides gave less trouble. C. pteridioides even survived and is still growing well (1980) in a wall out of doors without any attention in the garden of the senior author (TR) in Agarone (southern Switzerland) for c. eight years. C. guanchica also grew there for c. three years, but has succumbed since. Of C. hispanica we regularly got ample prothalli and also baby sporophytes, but these invariably succumbed when reaching $2-4 \mathrm{~mm}$ size. This species may be an extreme lime hater.

Experimental hybridization was performed in Budapest (GV and AM) as described by Lovis (1968). In wild hybrids some fronds or pinnae with immature sporangia were fixed, if possible still in the field, and the plant (or part of it) carefully dug out, immediately wrapped in moist moss (or moist clean filter paper) and plastic and brought into cultivation in Basel. Usually some limited vegetative propagation (by splitting of rhizomes) was possible. The plants usually could be kept for $2-4$ years in pots in good state until examination was complete.

Fixing of immature sporangia to study meiosis was done in glacial acetic acid ( 1 part) freshly mixed with abs. ethanol ( 3 parts). They were kept, if possible (c. 3 days), at $3-5^{\circ} \mathrm{C}$ and, if necessary, preserved at $-15^{\circ} \mathrm{C}$ until examination was possible. Staining with acetocarmine, squashing and making permanent preparation were done as described by Manton (1950: 295-296). Root tips to study mitosis were pretreated first in $0.1 \%$ aqueous colchicine solution for 5-6 
hours at $3-5^{\circ} \mathrm{C}$, then after quick elimination of all liquid on blotting paper, fixed in glacial acetic acid - abs. ethanol mixture as above. Before staining and squashing these root tips were softened by enzymatic degredation with crude snail cellulase (see Fabergé 1945; Roy \& Manton 1965).

\section{GENOME FORMULAE FOR SPECIES AND HYBRIDS}

For the less specialized reader we give here a short explanation about the meaning of genome formulae which are often used for explaining the constitution and behaviour of hybrids and allopolyploid species. For this purpose we chose C. maderensis (MM), C. persica (SS), their diploid hybrid, C. maderensis $x$ persica (MS) and C. pteridioides (MMSS) as an example, anticipating the fact (proof see below) that C. pteridioides is an allotetraploid species resulting from chromosome doubling in the diploid hybrid.

\subsection{BEHAVIOUR OF A SPECIES}

C. maderensis as any other diploid sexual species of Cheilanthes in the investigated group has in the nucleus of each of its somatic (sporophytic) cells two equal sets of 30 different chromosomes. We can designate such a set (= genome) as $M$. The sporophyte is therefore asøigned the genome formula (MM) making 60 chromosomes all together. These can best be seen (in high magnification) as 60 single bodies in a root tip preparation just before mitotic cleavage, see fig. 9b in Vida et al. 1971. But a diploid hybrid would also give the same picture in a root tip preparation, see fig. $5 \mathrm{~b}$ and $5 \mathrm{Ab}$.

On the other hand the first meiotic division (reductive cleavage) in the spore mother cells preceding spore formation give a different picture in a species and in a hybrid respectively. During this process the 60 chromosomes (MM) in C. maderensis arrange themselves in a + equatorial plane as 30 pairs, where each chromosome of one set has found and combined with the homologue of the second set. This is best visible in the appropriate states (diakinesis and metaphases) in unripe sporangia. Formation of 30 pairs in meiosis (usually formulated as $30^{\mathrm{II}}$ ) is the proof that the plant was a fertile diploid species (possessing two homologue genomes), see fig. 9A in Vida et al. (1971: 244).

After this stage the 30 pairs (60 chromosomes) are separated producing two haploid cells each with only 30 chromosomes (i.e. one genome M). This state remains constant in the spores, the prothalli and the gametes. Fusion of two gametes (each $=M$ ) during fertilization produces the zygote (MM) which is the origin of a new sporophyte $(\mathrm{MM})$.

\subsection{BEHAVIOUR OF A DIPLOID HYBRID AND POSSIBLE CHROMOSOME DOUBLING}

We assign the letter $S$ to each genome of the other diploid parent $C$. persica (SS). When making the hybrid of C. maderensis (MM) and C. persica (SS), there will be one gamete (M) fusing with the other gamete (S) producing a sporophyte of the diploid hybrid (MS). This will in root tips and other sporophytic tissues also show 60 chromosomes (as single bodies). On the other hand, in spore mother 
cells during meiosis practically no homologues between (M) and (S) are present. Instead of 30 pairs (like in a species), c. 60 univalents (formulated as c. 60I) are seen (or occasionally one or a few bivalents), see fig. 6.1,3 and 6A.1,3 . Such a picture (irregular meiosis) is typical of an interspecific hybrid. Formation of normal (haploid) spores is therefore impossible, the sporangial content is predominantly abortive material, see fig.4.3. Some diplospores, however, may be present, formed in a process of nuclear restitution, when the spore mother cell, without finishing its division, proceeds to mitotis cleavage. Such diplospores will have the formula (MS), and produce, after germination, a diploid prothallus (MS) with diploid gametes (MS) and such gametes by fertilization (MS + MS) an allotetraploid sporophyte (MMSS). In this particular case C. pteridioides is the result of the process and we have some evidence that it could be repeated under experimental condition, see fig. 1. The plants synthesized in this way (see below) have been found to be tetraploid, but are still too small to say that they completely match the natural species. We hope that they survive and that final results will be available next year.

\section{$\frac{\text { C.pteridioides }}{\text { (MMSS) }}$}

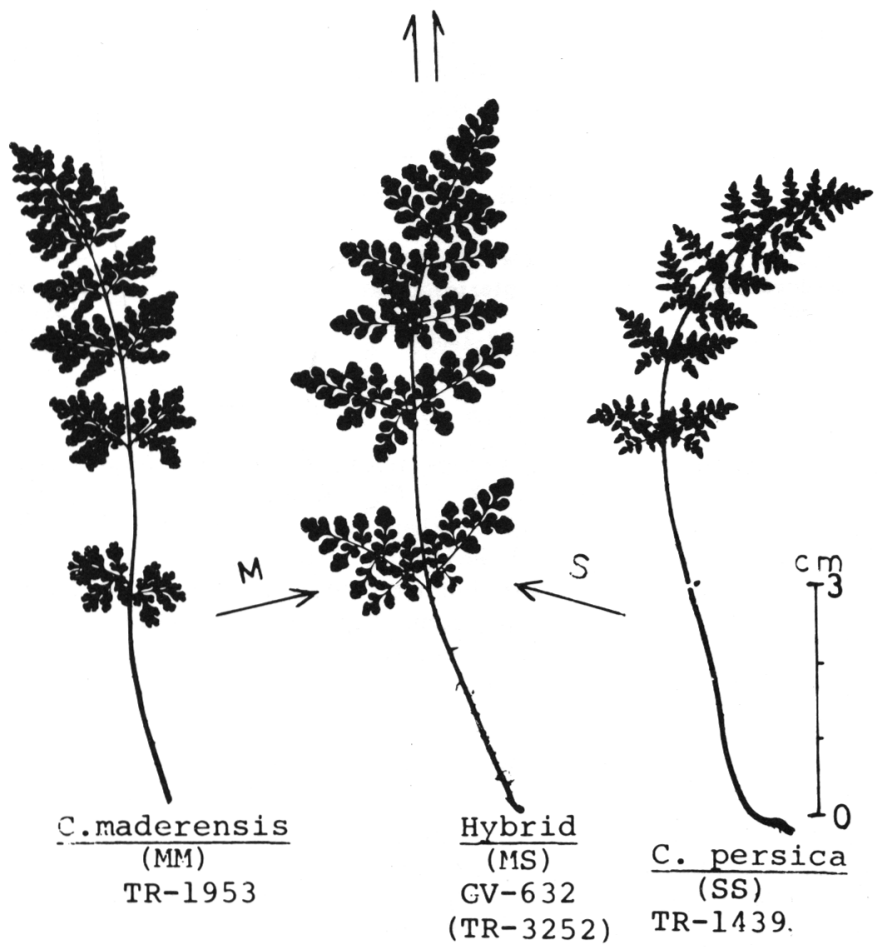

Fig. 1. Silhouettes of fronds. The hybrid of C.maderensis $\mathbf{x}$ persica (MS) between its parents (MM) and (SS) and formation of $\mathrm{C}$. pteridioides (MiMSS) by chromosome doubling, as deduced from genome analysis of backcrosses and also observed under experimental conditions. 
Fig. 1 shows the morphology of the hybrid (MS) which is very similar to the allotetraploid C. pteridioides (MMSS). This confirms the general experience that doubling of chromosomes has usually very little influence on gross morphology. The intermediate position of $C$. pteridioides beetween its ancestors refers not only to the shape of fronds but also to some details, in particular to the border of the pseudo-indusium (see fig. 2). In C. maderensis (MM) this border is glabrous, in C. persica (SS) it carries long (c. $1.5-3 \mathrm{~mm}$ ) whitish, ribbon-like hairs covering the whole lamina. In the allotetraploid C. pteridioides (MMSS) these hairs reach only $0.1-0.5 \mathrm{~mm}$ in length, producing a cilliate border. This is the best character for identification of the species. The same ciliate border is present in the diploid hybrid (MS).
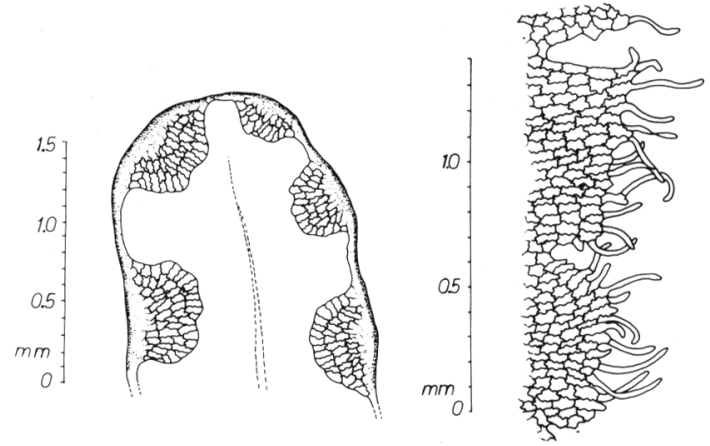
Ch. maderensis (MM) TR-1490
Ch. pteridioides
(MMSS)

$$
\text { TR-1488 }
$$

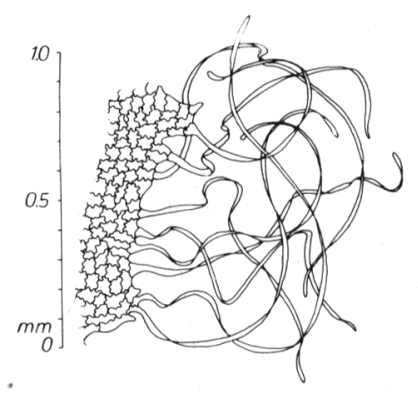

Ch. persica TR-2310

Fig. 2. Border of the pseudo-indusium in Ch. pteridioides (MMSS) and its ancestors: $\mathrm{A}=\mathrm{Ch}$. maderensis (MM), pinnule with pseudo-indusium, border glabrous. C = Ch persica (SS), with long (c. $1.5-2.5 \mathrm{~mm}$ ) whitish, ribbon-like hairs, covering the whole lamina, but born on this border. $\mathrm{B}=\mathrm{Ch}$. pteridioides (MMSS), hairs present but only $0.1-0.4 \mathrm{~mm}$ long, forming a ciliate border. (Drawings by H. Rasbach, partly reproduced from RASBACH et al., 1982).

\subsection{TRIPLOID HYBRIDS INCLUDING BACKCROSSES}

A hybrid between C. pteridioides (MMSS) producing gametes (MS) and C. pulchella (PP) producing gametes (P) will be triploid (MSP) and show only (c. 90) or predominantly univalents in meiosis, because all three genomes are different and nohomologous chromosomes are present. This hybrid had been made and its behaviour (see plates II2, IIA2) accepted as proof that C. pteridioides is indeed an allo- (not an auto-) tetraploid species. The cross of an autotetraploid (say XXXX) with (PP) should have given a triploid hybrid (XXP) which by autosynthesis between the two $X$ genomes should show c. 30 pairs $(X X)$ and C. 30 univalents $(P)$. 
A different behaviour is shown by the "backcross" C. maderensis (MM) with C. pteridioides (MMSS). Fusion of the parental gametes (M) with (MS) gave a triploid hybrid (MMS), which in meiosis produced c. 30 pairs (MM) and c. 30 univalents (S) (see fig. 6.4, 6A.4). Together with the mentioned result that $C$. pteridioides is an allotetraploid, this was taken as proof that C. maderensis was one of its ancestors.

A quite analogous result was obtained in the hybrid between C. persica (SS) producing gametes (S) and C. pteridioides (MMSS) with gametes (MS). The triploid hybrid (MSS) again gave c.30II $+30 \mathrm{I}$ in meiosis (see fig. 6.2,6 A.2) showing that C.persica was the second ancestor.

These results gave the basis and stimulus to resynthesize C. pteridioides as mentioned above. Other triploid hybrids are listed below.

\subsection{TETRAPLOID HYBRIDS}

These can be analysed in a similar way, as, for example the experimental hybrid $C$. guanchica $x$ pteridioides and the natural hybrid C. guanchica $x$ tinaei listed below.

\section{LIST OF ALL THE TWELVE HYBRIDS WHICH WERE EXAMINED WITH CYTOLOGICAL RESULTS}

\subsection{NATURAL HYBRIDS}

In these it is not known which was the $q$ and which $\sigma^{7}$ parent. Fig. 5 and $5 \mathrm{~A}$ give results of cytology.

(1) C. $x$ teneriffae Rasbach \& Reichstein (1980) = C. maderensis $x$ pulchella, coll. H. \& K. Rasbach 11.4.1978, № RAS-31, since then cult. in Basel (TR-4649). Root tip diploid, $2 n=c .60$ (GV in litt. 26.5.1978) with c. 60 univalents in meiosis, see fig.5b. This hybrid is of particular interest as putative parent of allotetraploid C. guanchica, in morphology including shape of pseudo-indusium it is a nearly perfect match to C. guanchica, but the sporangia contain predominantly abortive material.

(2) C. $\mathbf{x}$ iberica Rasbach \& Reichstein (1980) = C. hispanica $\mathbf{x}$ tinaei, coll. H. Kunz \& T. Reichstein 13.4.1965, № TR-1500-A, since then cult. in Basel, then in Leeds. Triploid with $2 \mathrm{n}=\mathrm{c} .90$ and $\mathrm{n}=\mathrm{c}$. $30 \mathrm{II}+30 \mathrm{I}$, see fig. 13E, F in Vida et al. (1971: 248-249). This is compatible with theassumption that C. hispanica is one ancestor of $C$. tinaei, giving the genome formula HHM for the hybrid. But the rigid proof that C. tinaei is allo- (not auto-) tetraploid is still lacking.

(3) C. $x$ insularis Rasbach \& Reichstein (1980) = C. guanchica $x$ tinaei, coll. H. \& K. Rasbach \& T. Reichstein 28.5.1977, since then cult. in Basel (TR-4135). Tetraploid hybrid, in meiosis 32-42 pairs were counted, the remaining (36-56) were univalents in different cells, see fig. 5 with a cell showing $38 \mathrm{II}+49 \mathrm{I}$. This is distinctly more bivalents than expected (theoretical value is $30 \mathrm{II}+60 \mathrm{I}$ ), but it is rather difficult to get good spreading and precise counts in this hybrid. The appearent number of bivalents may be bigger than it really is when some univalents laying on top of each other are taken as a bivalent. On the other hand, the possibility of some limi- 
ted pairing between chromosomes of $\mathrm{H}$ and $\mathrm{P}$ genomes cannot be excluded. The result is therefore still compatible with the theoretical genone formula (HMMP).

\subsection{EXPERIMENTAL HYBRIDS}

Here the female parent is always mentioned first in the name. Figures 6, 6A, 7 and $7 \mathrm{~A}$ give results of cytology, fig. 8 and 9 show silhouettes of pressed fronds of parents and hybrids with intermediate morphology. Only the herbarium numbers of the parents are given here; for the origin of the plants see the appendix.

(4) C. persica $x$ maderensis (SM). Three sets of this important hybrid have successfully been raised, using $C$. maderensis of three different origins. GV-541 from TR-2322 x 3047; GV-624 from TR-2322 x 1954 and GV-632 from TR-2322 x 2030. All were diploid and showed similar morphology. Meiosis of a cell in GV-624 with 60 univalents (as mentioned in the text) is given in fig. 6.1 and $6 \mathrm{~A} .1$.

Morphology of this hybrid and the reverse cross (5) including the details of the shape of the pseudo-indusium with fimbriate border completely match C. pteridioides, only the texture was slightly less coriaceous. Ripe sporangia contain mainly abortive material, but also a few well formed diplospores (see fig. 4.3). A plant of this hybrid (GV-623) was brought to Basel on 22.2.1971 and since then cultivated here (TR-3254) on limestone containing soil, out of doors in summer, in the cold greenhouse in winter and was used for sowing (see below). This hybrid could perhaps still be formed in nature today because C. persica is still growing on Mt. Mauro in Italy (Corbetta 1980: 101 - 2; Córbetta \& Zanotti Censoni 1981; Rossi 1981) and is not extinct there as formerly assumed (Nardi et al. 1978: 4). The probability to find it is, however, low because the nearest known localities of $\mathrm{C}$. maderensis in Italy are more in the West. Formation of C. pteridioides as judged from its present wide distribution must have happened very long ago and it is likely that the two ancestral species have grown more closely together at that time.

(5) $C$ maderensis $x$ persica (MS). GV-659 = TR-1954 $\times 2322$, the reverse cross, diploid, with 60 univalents in meiosis (see fig.6.3 and 6A.3). Morphology and content of sporangia like the above hybrid (4). This hybrid will probably behave in a similar manner as (4) but its a bility to produce progeny has not been examined.

(6) C. persica $\times$ pteridioides (SMS). GV-499 $=\mathrm{TR}-2310 \times 1601$, triploid with c. 30 II +30 I in meiosis, a cell with precisely this result is reproduced in fig. 6.2 and $6 \mathrm{~A} .2$. In connection with the fact that $\mathrm{C}$. pteridioides is an allo- (not auto-) tetraploid species (see hybrid (10), this result shows that $C$. persica is one of its ancestors. Ripe sporangia contain mainly abortive material. One plant (GV-499-1) of this hybrid was brought to Basel on 6.9.1971 and cultivated as TR-3255. This hybrid could perhaps be found in the E-Mediterranean region including Turkey, where the two parental species sometimes grow together.

(7) C. maderensis $x$ pteridioides (MMS). GV-471 $=$ TR-2030 $\times 1601$, triploid with c. $30 \mathrm{II}+30 \mathrm{I}$ in meiosis, see fig. 6.4 and $6 \mathrm{~A} .4$. This shows that C. maderensis is the other ancestor of C. pteridioides. Ripe sporangia contain mainly abortive material. The reverse hybrid C. pteridioides $x$ maderensis $(\mathrm{MSM})=(\mathrm{GV}-481-18=\mathrm{TR}-1468 \times 2030)$ 
was also made and brought to Basel, cultivated as TR-3260, meiosis showed the same picture. This hybrid could perhaps be found in the W-Mediterranean region, where the two parent species sometimes grow together.

(8) C. guanchica $x$ pteridioides (MPMS). $A M-43=T R-1956 \times 1600$, tetraploid with c. $30 \mathrm{II}+60 \mathrm{I}$ in meiosis, a well spread cell showing precisely this number is given in fig. 6.5 and $6 \mathrm{~A} .5$. This shows that the two species must have one ancestor in common, which in this case is C. maderensis $(M M)$, while the other genomes ( $P, S)$ are different. Ripe sporangia contain mainly abortive material. This hybrid is a vigorous grower. It (or the reverse cross) has meanwhile been found in nature (Spain) and described as C. $x$ malacitensis Rasbach \& Reichstein (1982).

Two sets of the reciprocal cross. C. pteridioides $x$ guanchica have also been made: GV-465 = TR-1468 $\times 1915$ and GV-482 = TR-1602 $x$ 1915. They showed quite similar morphology and the same behaviour in meiosis.

(9) C. pulchella $\times$ guanchica $(P P M) \cdot G V-483=T R-1958 \times 1915$, triploid with $30 \mathrm{II}+30 \mathrm{I}$ in meiosis, see fig. 7.1 and $7 \mathrm{~A} .1$ showing that C. pulchella is one ancestor of C. guanchica. Ripe sporangia contain mainly abortive material. This hybrid could well grow in the Canary Islands where both parent species are native.

(10) C. pteridioides $\times$ pulchella (MSP). GV-498 = TR-1468 $\times 1958$, triploid with 90 univalent chromosomes in meiosis, see fig.7.2 and 7A.2, showing that C. pteridioides is an allo- (not auto-) tetraploid as discussed in the text. Ripe sporangia contain mainly abortive material. This hybris is a vigorous grower, but it cannot be expected to be found in nature as no places are known where the parents grow together.

(11) C. guanchica $\times$ maderensis $(M P M) \cdot G V-497=T R-1915 \times 2030$, triploid with c. $30 \mathrm{II}+30 \mathrm{I}$ in meiosis, see fig. 7.3 and $7 \mathrm{~A} .3$, showing that C. maderensis is the second ancestor of C. guanchica. Ripe sporangia contain mainly abortive material. This hybrid could well be found in the Canary Islands and W-Mediterranean area where both parents are known to grow sometimes together.

(12) C. guanchica $x$ persica (MPS). AM-62 $=\mathrm{TR}-1914 \times 2322$, triploid with 90 univalents in meiosis, see fig. 7.4 and $7 \mathrm{~A} .4$, showing that C. guanchica is an allo- (not auto-) tetraploid species. Ripe sporangia contain only abortive material. This hybrid cannot be expected to occur in nature. Since C. persica is nearly extinct in Italy, no places are known where the two parents grow together. As can be seen in the genome formulae, this hybrid has exactly the same genomic constitution as (10) C. pteridioides $x$ pulchella, both contain one genome each of (M) (P) and (S). It is therefore understandable that both hybrids show the same morphology. It is indeed impossible to differentiate them, neither by classical morphological nor by cytological methods. They only differ in a historical way, i.e. in their mode of formation. The first $(10)$ is derived from $C$. pteridioides $x$ pulchella, i.e. by fusing $M S+P$, while the second (12) from $C$. guanchica $x$ persica, i.e. by fusing $M P+S$, the result in both cases is the same $=M+P+S$. Nevertheless making these two hybrids was quite important for this study to establish the allotetraploid nature of both C. pteridioides and C. guanchica. 


\section{DISCUSSION}

Complete failure of pairing during meiosis in the hybrids (10) and (12) shows that both C. pteridioides and C. guanchica are allo(not auto-) tetraploid species. The formation of $\mathrm{c}$. $30 \mathrm{II}+30 \mathrm{I}$ in the triploid hybrids (6) and (7) shows that C. maderensis (MM) and C. persica (SS) must be the ancestors of C.pteridioides (MMSS). In a similar way the formation of c. 30 II $+30 \mathrm{f}$ during meiosis in the hybrids (9) and (11) shows that C. maderensis and C. pulchella are the ancestors of C. guanchica. This has already been anticipated by Benl (1966) for his C. sventenii pro hybr. based of morphological reasons at a time when he not yet realized that it was synonym with C. guanchica.

Unfortunately a rigid proof that C. tinaei, the third tetraploid species in our group, is also allo- (not auto-) tetraploid, is still missing. But its intermediate morphology between C. hispanica and C. maderensis is so evident that we are confident that our assumption of its being once formed by chromosome doubling from a diploid hybrid between C. hispanica $x$ maderensis will be correct. Cytological results in the two natural hybrids (2) and (3) do well agree with this assumption. They also show that, provided the allotetraploid status is correct, only C. hispanica ( $\mathrm{HH}$ ) and $\mathrm{C}$. maderensis (MM) can be its ancestors. Difficulties for further experimental work were mainly due to the fact that we did not succeed so far to raise or keep C. hispanica in cultivation. Meanwhile the natural hybrid $C$. maderensis $x$ tinaei has been found. Examination of its cytology (not yet possible) should show whether it agrees with the genome formula (HMM).

\section{FORMATION OF C. PTERIDIOIDES UNDER EXPERIMENTAL CONDITIONS}

a) Sowing of sporangia content of the hybrid (4) = GV-623= C. persica $x$ maderensis (TR-2322 x 2030) in Nov. 1971 in Budapest gave several prothallia and finally four young sporophytes. One of them was checked in root tip mitosis and found to be tetraploid. Unfortunately these plants died during a disorganized period when one of us (GV) had to move to other buildings in the university. Thus we have no documentation of this progeny.

b) Sowing of sporangia content of the same hybrid (4) = GV$623=(\mathrm{TR}-2322 \times 2030)=\mathrm{TR}-3254$ in Basel on 12.1.1972 gave no growth, repetition on 6.9 .1972 and 7.9 .1973 was negative again. But after keeping the plant in summer 1979 out of doors, it became more vigorous and sowing on 12.1 .1980 gave clean prothallia which could be planted on soil (8.4.1980) and gave seven sporophytes in summer. We hope some may become fertile in 1981, so that we can publish the documentation later.

NB. During this experiment not a single plant of C. pteridioides was growing in the garden where the hybrid grew, so the progeny cannot be just a weed from foreign spores.

\section{EVOLUTION AND DISTRIBUTION}

The mentioned analysis leads to the interpretation given in fig. 3 for the probable evolution of present species of Cheilanthes in the investigated group. Four ancestral diploids which may have evolved 
in remote times from a common ancestral stock are rather distinct, but have nevertheless important features in common and are able to hybridize and to produce allotetraploids. Allopolyploidy always leads to a reticulate evolution (see the excellent example for $\mathrm{N}$-American Asplenium in Wagner 1954) and partly reverses the diversification which separate evolutionary lines have produced. Allopolyploids therefore often produce taxonomic problems by blurring the different characters of the ancestral diploid species, thus making identifications difficult. This was obviously the reason why the three allotetraploids (or at least two of them) have so long escaped proper recognition in Europe.

Theoretically our four diploids could produce a maximum of six allotetraploids. Probably for geographical reasons only three of them have actually been formed. C. maderensis occupies a central position in this process. The three existing allotetraploids originated by chro-

\section{HHMM MMSS MMPP}

C.tinaei

C.pterid. C.guanch.

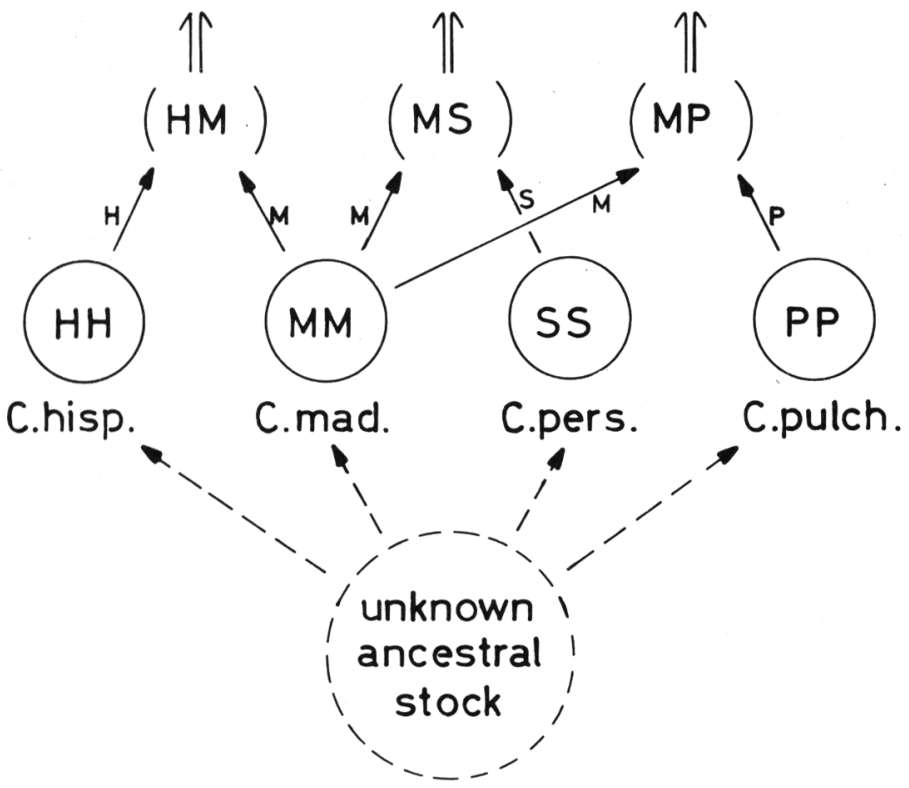

Fig. 3. Probable evolution of three allotetraploid species from four ancestral diploids. C. maderensis (MM) in central position, for geographical reasons was able to hybridize with the three other diploids. For these reasons the other three theoretically possible allotetraploids (HHSS, HHPP and SSPP) have obviously not been formed. 
mosome dubling in the three hybrids of $C$. maderensis with the three other diploids. These three other diploids probably could not hybridize with each other for geographical reasons again. Taking present day distribution of the diploids as a guide, one can speculate where each of the these allotetraploids has originated.

C. tinaei (HHMM) most probably had its origin in the western Mediterranean area, particularly in the Iberian peninsula, where both, C. hispanica and C. maderensis, together with C. tinaei are still native. Obviously it may have formed more than once and it is possible that it is still occasionally formed even today. On the other hand its presence in Madeira (where C. hispanica is absent) and in an island in the Marmara sea, Turkey (where both ancestors are absent), shows that it is an old species, capable of some long range distribution.

For $\dot{C}$. pteridioides (MMSS) a new formation in nature is still possible today, but not very likely. The present-day distribution of its ancestor just nearly touch in Italy. C. maderensis is known in Macaronesia and the W-Mediterranean basin including Italy along its south-western costal regions and islands. C. persica is found from Italy on eastward through W-Asia to the Himalaya; its only known station in Italy is on Mt. Mauro (Appennino romagnolo, Prov. di Ravenna, c. $15 \mathrm{Km}$ WSW of Faenza). But probably some time ago the area of both ancestors did overlap somewhere in Italy or not far from it, and it must have been in this region where C.pteridioides came into existense. Today it is present on the Cap Verde Islands (absent in the Azores, Canaries and Madeira) through the whole Mediterranean region, $W$-Asia to the Himalayas. It is obviously a rather old species with remarkable spreading power.

The place of origin of C. guanchica (MMPP), in agreement with its name (guanches is the name of the aborigines of the Canary Islands), are obviously the Canary Islands, where both ancestors are still present together with C. guanchica, and where C. pulchella is endemic. It is possible that it may be occasionally formed there de novo even today, as the discovery of $C . x$ teneriffae demonstrates. Its presence in the $W$-Mediterranean area shows that it is nevertheless a rather old species, capable of long range distribution. The other possibility that $C$. pulchella was once native in the $W$-Mediterranean area cannot be excluded, but is less likely and would not upset the deduction that $C$. guanchica must be an old species.

\section{APPENDIX}

\section{ORIGIN OF PLANTS OR SPORES USED FOR EXPERIMENTAL WORK}

\section{C. maderensis:}

- TR-1954. Canary Islands, Tenerife, volcanic rocks, along path to Masca, c. $650 \mathrm{~m}$. alt., 28.3.1967, leg. E.R.S. Sventenius, P.R.O. Bally, H.L. \& T. Reichstein. Two plants taken living, cultivated in Basel and in Budapest. $2 n=60$ (15.7.1968); $n=30$ (4.3.1970), det. GV.

TR-2030. Corsica, silicate rocks, along road between llle de Rousse to Costa, c. $10 \mathrm{~km}$ of Costa, c. $200 \mathrm{~m}$. alt., 13.7.1967, leg. H. Kunz \& T. Reichstein. since then cultivated in Basel and Budapest. $2 \mathrm{n}=60 ; \mathrm{n}=30(11.6 .1968)$, det. GV, see fig. 9-10 in Vida et al. 1971 . 


\section{C. persica :}

TR-2310. Turkey. S-exposed granitic rocks, aside of bridge over the river Kizilirmak, c. $770 \mathrm{~m}$. alt., along road from Ankara to BelaKaman (33 Km.). 23.9.1968, leg. Demiriz \& T. Reichstein. Since then cultivated in Basel in Budapest. $2 \mathrm{n}=60(4.3 .1970) ; \mathrm{n}=30$ (e.11. 1968), det. GV, see fig. 9-10 in Vida et al. 1971.

TR-2322. Turkey, Vilajet Analya above Cubuk bogazi, in rocks (partly limestone) at c. $920 \mathrm{~m}$. alt., 28.9.1968, leg. H. Demiriz \& T. Reichstein. Since then cultivated in Basel and Budapest. $2 \mathrm{n}=60$ (17. 2.1970); $n=30$ (fixed in the field), det. GV, see fig. 9-10 in Vida et al. 1971 .

\section{C. pulchella:}

TR-1958. Canary Islands, Tenerife, Barranco del Agua, above Güimar, relict of laurel forest at c. $950 \mathrm{~m}$. alt., 31.3.1967, leg. P.R.O. Bally, H.L. \& T. Reichstein. since then cultivated in Basel and Budapest. $2 \mathrm{n}=60(20.5 .1968) ; \mathrm{n}=\mathrm{c}$. 30 , see fig. 11-12 in Vida et al. 1971 .

\section{C. pteridioides :}

TR-1468. Balearic Islands, Mallorca, limestone rocks in olive grove near Can Gomila, S of Sóller, c. $130 \mathrm{~m}$. alt., February 1965, leg. J. Orell. Obtained in Basel 15.2.1965, cultivated there, spores to Budapest. $2 \mathrm{n}=60(17.2 .1970) ; \mathrm{n}=30$ (11.6.1968), see fig. $9-10$ in Vida et al. 1971.

TR-1600. Turkey, along road from Tarsus to Gülek pass (c. 20 $\mathrm{km}$. from Tarsus) at c. 150-300 m. alt., October 1965, leg. E. Hauser. Since 5.10.1965 cultivated in Basel and Budapest. $2 \mathrm{n}=120$ (8.2.1970); $\mathrm{n}=60$, det. GV.

TR-1601. Turkey, along road from Silifke to Konya at c. $150-$ $300 \mathrm{~m}$. alt., mainly on limestone rocks, partly in grass, common on both sides of road. October 1965, leg. E. Hauser. Since 5.11.1965 cultivated in Basel and Budapest. $2 \mathrm{n}=\mathrm{c} .120(10.2 .1968) ; \mathrm{n}=60(8.5$. 1969), det. GV.

\section{C. guanchica:}

TR-1914. Canary Islands, Gran Canaria, volcanic rocks and wall (without mortar), Los Chorros, near the road above San Mateo, c. $850 \mathrm{~m}$. alt. (partly together with C. maderensis), 23.3.1967, leg. G. Kunkel, P.R.O. Bally, H.L. \& T. Reichstein. since then cultivated in Basel and Budapest. $n=60$ (20.5.1968); $n=c .120$ (29.4.1969), det. GV.

TR-1915. Canary Islands, second plant from same place as TR1914. Cultivated in Basel and Budapest. $n=60 ; 2 n=120$ (13.3.1970), see fig. 13-14 in Vida et al. 1971 (sub C. "sventenii").

TR-1956. Canary Islands, Tenerife, Las Cañadas, lava rocks, c. 2200 m. alt., 30.3.1967, leg. E.R.S. Sventenius, P.R.O. Bally, H.L. \& $T$. Reichstein. Since then cultivated in Basel and Budapest. $2 \mathrm{n}=$ $120(17.2 .1970) ; \mathrm{n}=60$ (20.v.1968), see fig. $13-14$ in Vida et al. 1971. 


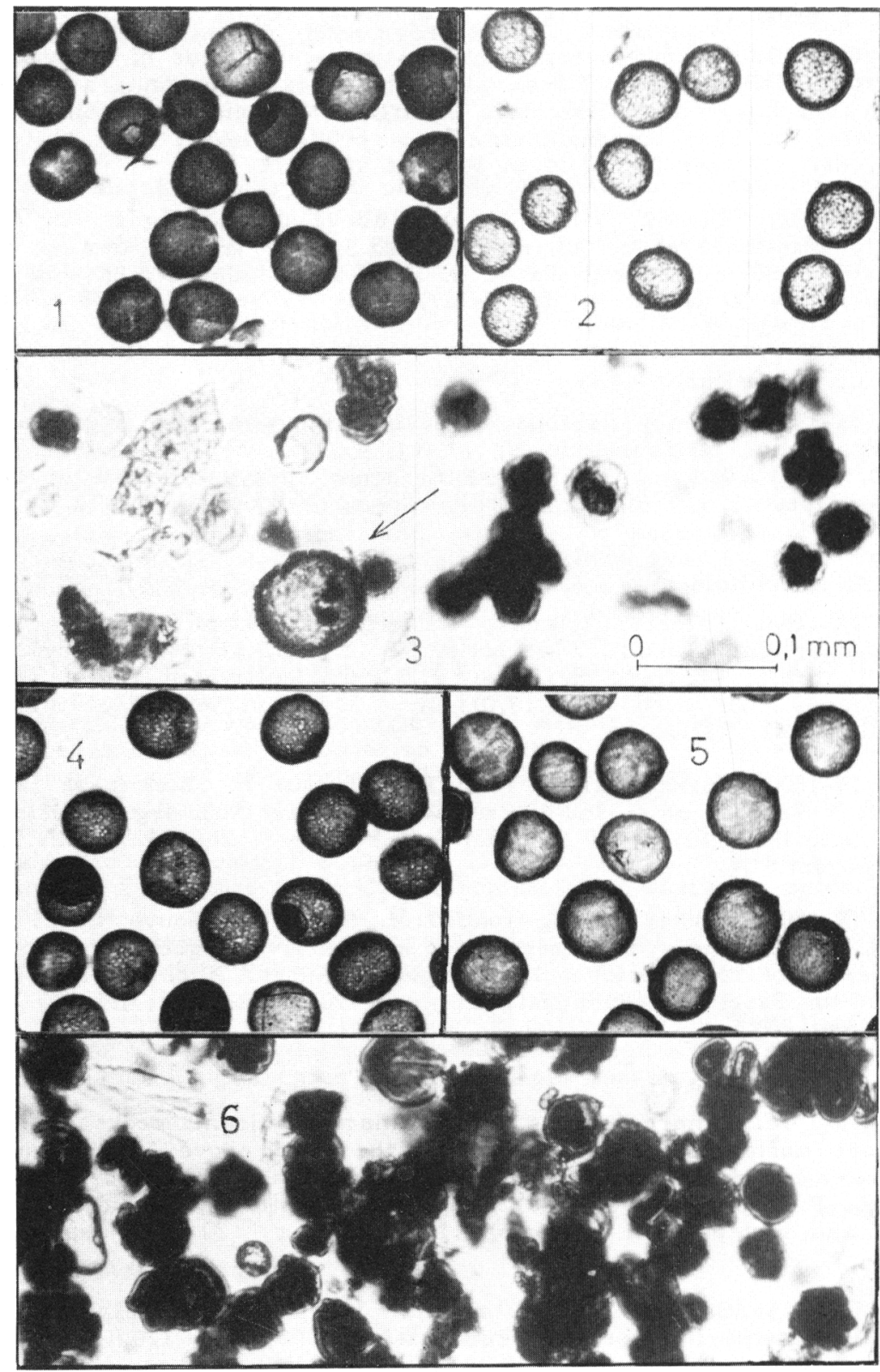

Fig. 4.- Content of ripe sporangia. $1=$ Ch maderensis (MM) TR2030, good small spores; 2 = Ch. persica (SS) TR-2322, good small spores; $3=$ Exper. hybrid Ch. persica $x$ maderensis (SM) GV-632 (= TR-3254), mainly abortive material with one big putative diplospore (arrow); $4=$ Ch. pteridioides (MMSS) TR-1601, good big spores; $5=$ Ch guanchica (MMPP) TR-1956, good big spores; $6=$ Exper. hybrid $C h$. guanchica $x$ maderensis (MPM), GV497-2 (= TR-3259), only abortive material visible. The other triploid and tetraploid hybrids gave a similar picture. 


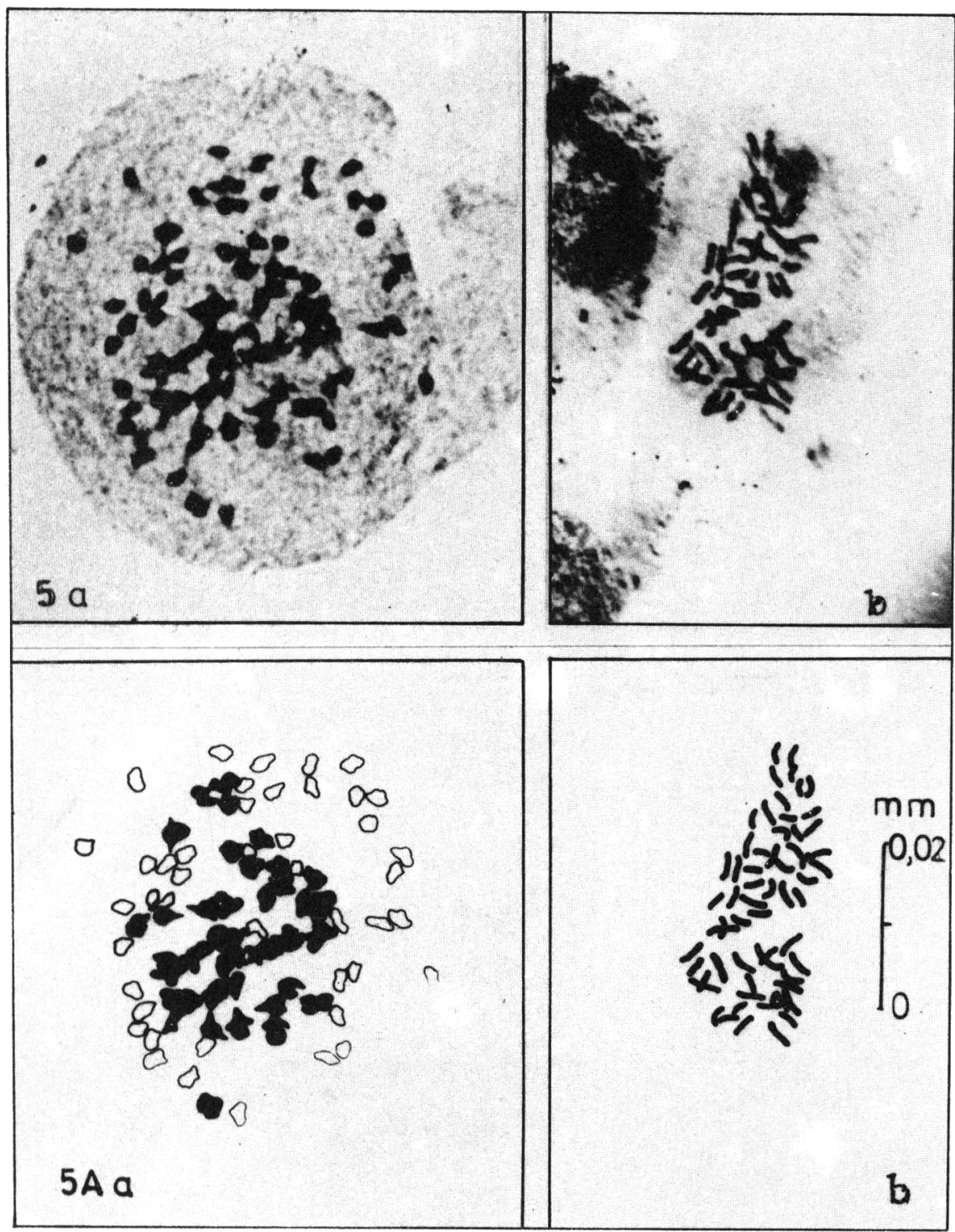

Fig. 5 and 5 A.- cytology of natural hybrids. $5=$ photographs, $5 \mathrm{~A}=$ explanatory diagrams of results from analysis showing bivalents black, univalens in outline. $\mathrm{a}=\mathrm{Ch} . \mathrm{x}$ insularis (HHPM) $(\mathrm{TR}-4135)=$ Ch. guanchica $(\mathrm{HHPP}) \times \mathrm{Ch}$. tinaei (HHMM), spore mother cell in meiosis showing $38 I I+44 I$, another cell showed $32 \mathrm{II}+56 \mathrm{I} \cdot \mathrm{b}=\mathrm{Ch} \cdot \mathrm{x}$ teneriffae $(\mathrm{MP})(\mathrm{RAS}-31=\mathrm{TR}-4649=\mathrm{Ch}$. maderensis (MM) $x$ Ch. pulchella (PP), root tip showing 60 univalents. All det. A.M. Meiosis of Ch. $x$ iberica (TR-1500A) is given in Vida et al. 1971, fig. 13-14. 


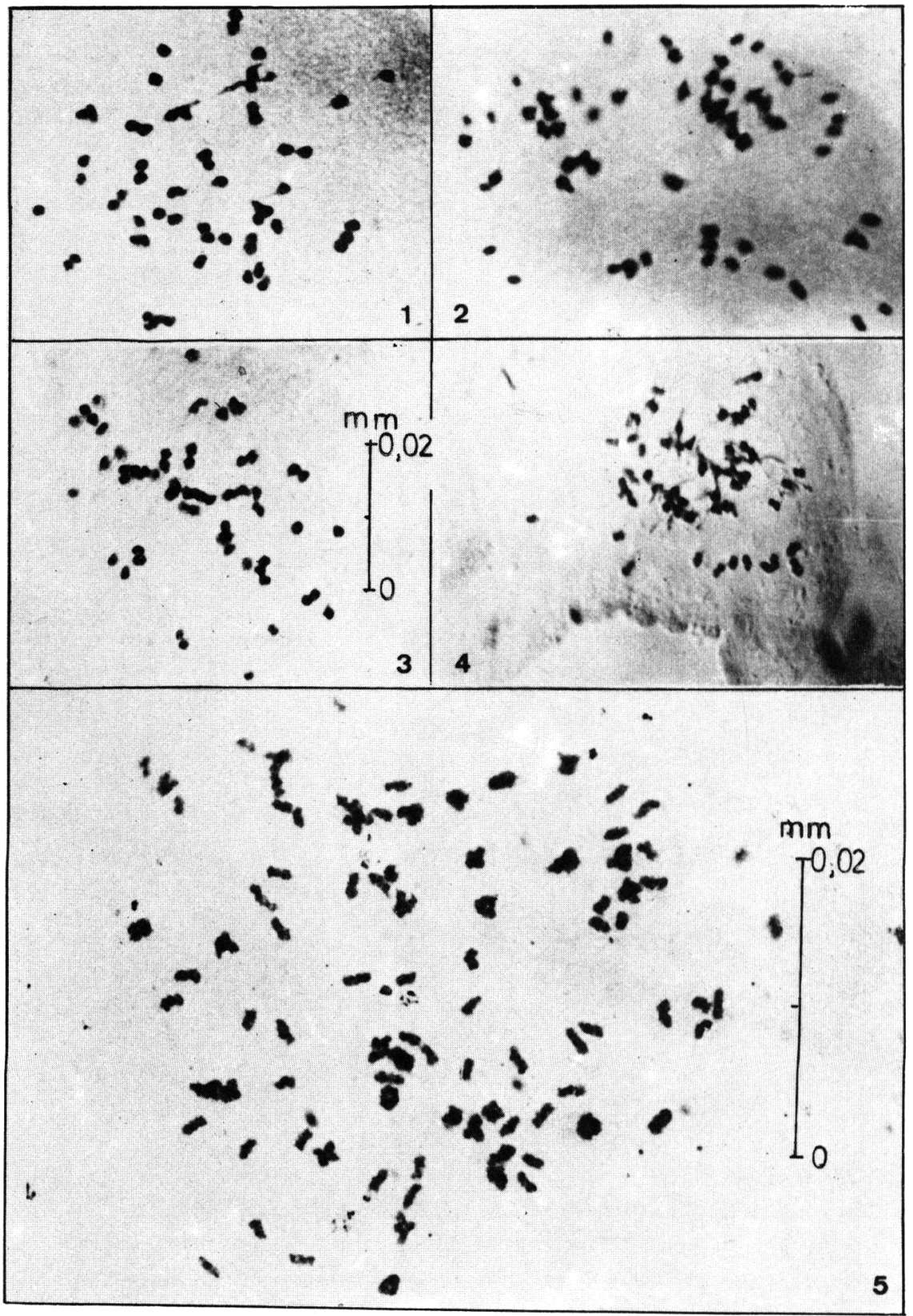

Fig. 6.- Cytology of experimentally produced hybrids. Photographs of spore mother cells in meiosis; $1,2,3,4=c .1000$ $\mathrm{x} .5=\mathrm{c} .2000 \mathrm{x} \cdot 1=\mathrm{Ch}$. persica $\mathrm{x}$ maderensis $(\mathrm{GV}-632) ; 2=$ Ch. persica $x$ pteridioides $(G V-499) ; 3=$ Ch. maderensis $x$ persica $(G V-659) ; 4=C h$. maderensis $x$ pteridioides $(G V-471) ; 5$ $=$ Ch. guanchica $\mathrm{x}$ pteridioides $(\mathrm{AM}-43)$, results of analysis see fig. 6A. 


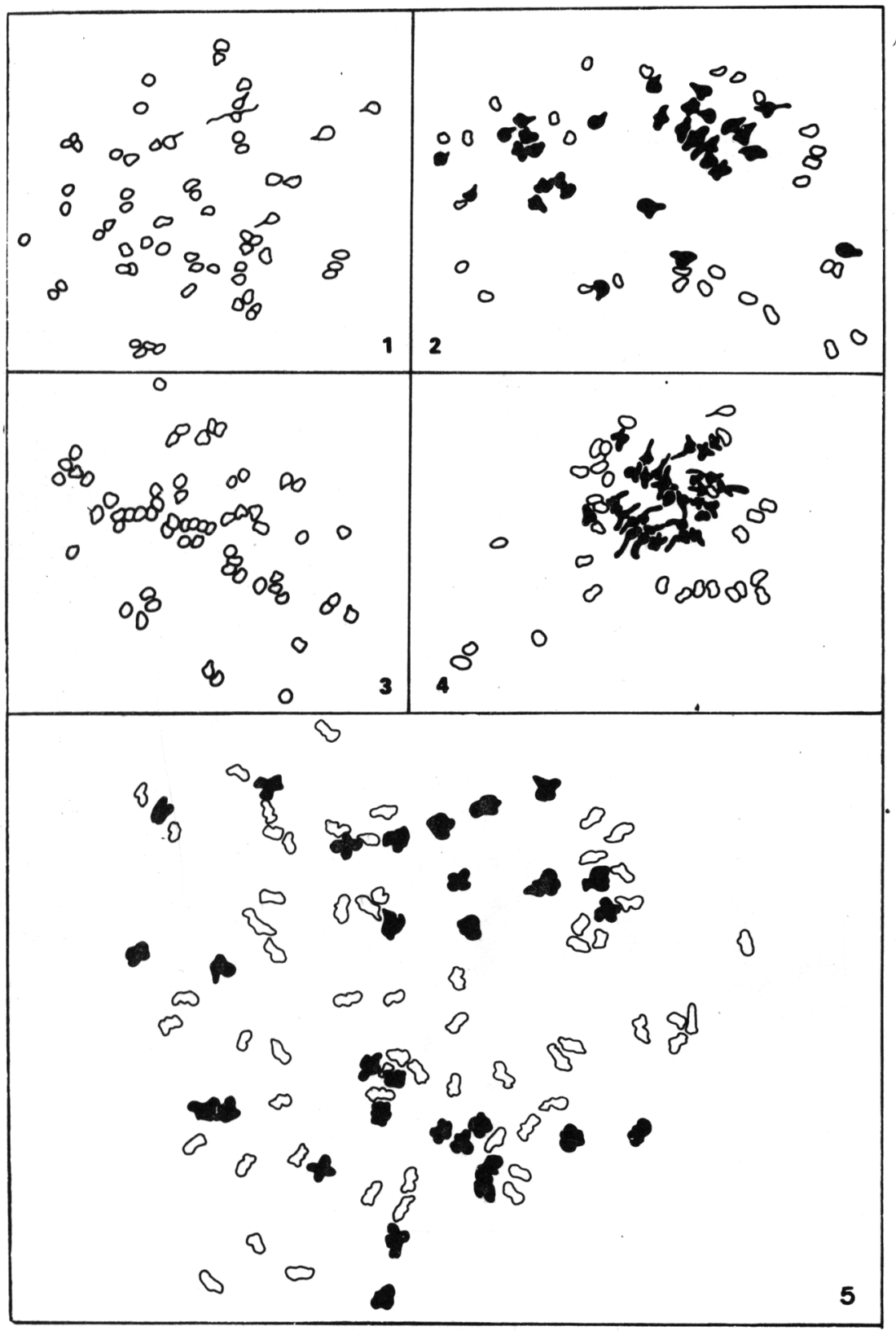

Fig. 6A.- Explanatory diagrams for fig. 6. Bivalents black, univalents in outline. $1=C h$. persica $x$ maderensis showing $60 \mathrm{I} ; 2=\mathrm{Ch}$. persica $\mathrm{x}$ pteridioides showing $30 \mathrm{II}+30 \mathrm{I} ; 3=$ Ch. maderensis $x$ persica showing $60^{I} ; 4=C h$. maderensis $x$ pteridioides showing $30 \mathrm{II}+30^{I} ; 5=\mathrm{Ch}$. guanchica $x$ pteridioides showing $30 I I+60 I$. 


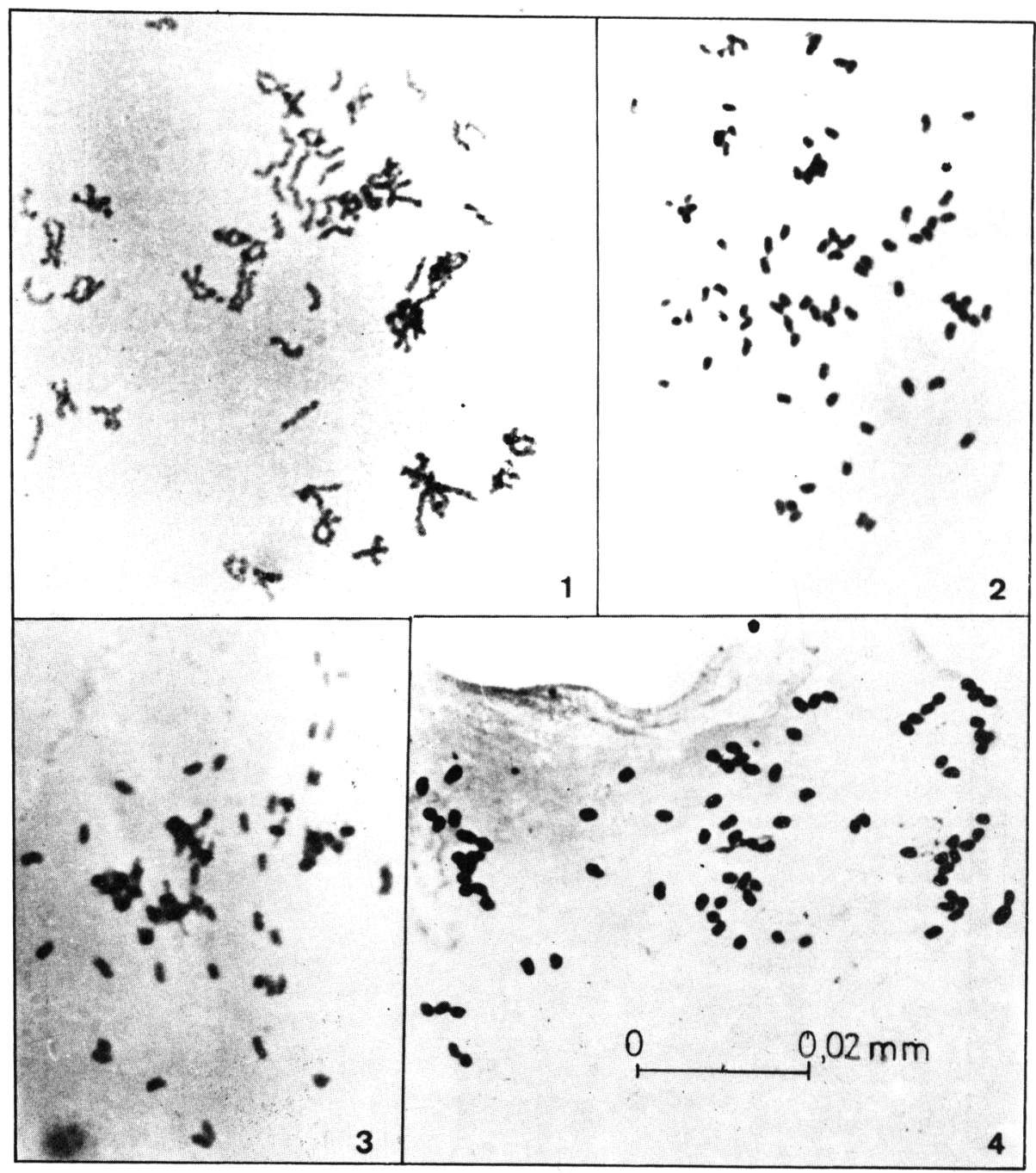

Fig. 7.- Cytology of experimental hybrids. Photographs of spore mother cells in meiosis, all c. $1000 \mathrm{x} .1=\mathrm{Ch}$. pulchella $\mathrm{x}$ guanchica $(\mathrm{GV}-483) ; 2=\mathrm{Ch}$. pteridioides $\mathrm{x}$ pulchella (GV498); $3=$ Ch. guanchica $x$ maderensis $(G V-497) ; 4=C h$. guanchica $x$ persica $(A M-62)$. 


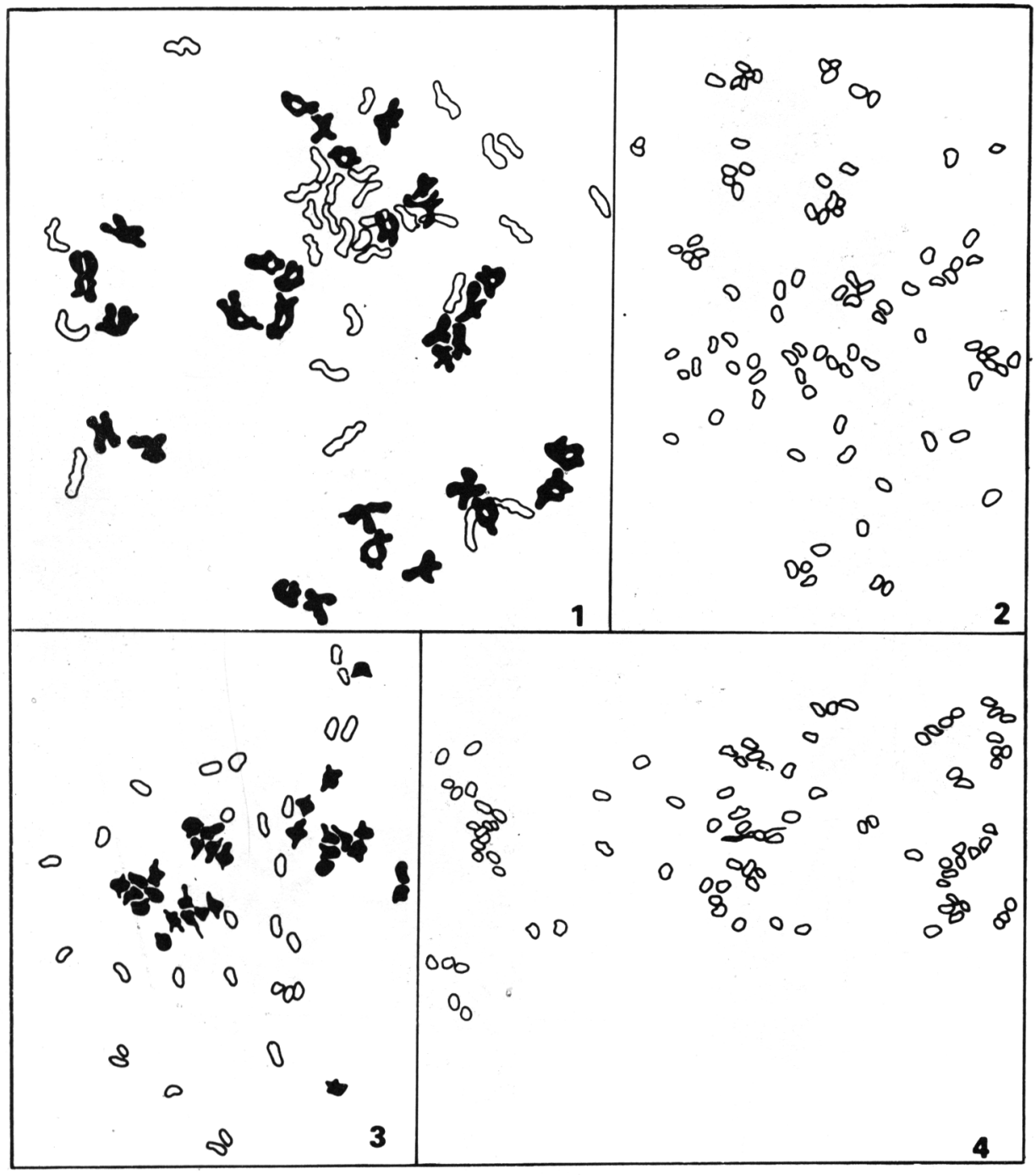

Fig. 7A.- Cytology of experimental hybrids. Diagrams (continuation).

1. Ch. pulchella $x$ guanchica showing $30 I I+30 I$.

2. Ch. pteridioides $x$ Ch. pulchella showing $90^{I}$.

3. Ch. guanchica $x$ maderensis showing $30^{I I}+30^{I}$.

4. Ch. guanchica $x$ persica showing $90^{I}$. 


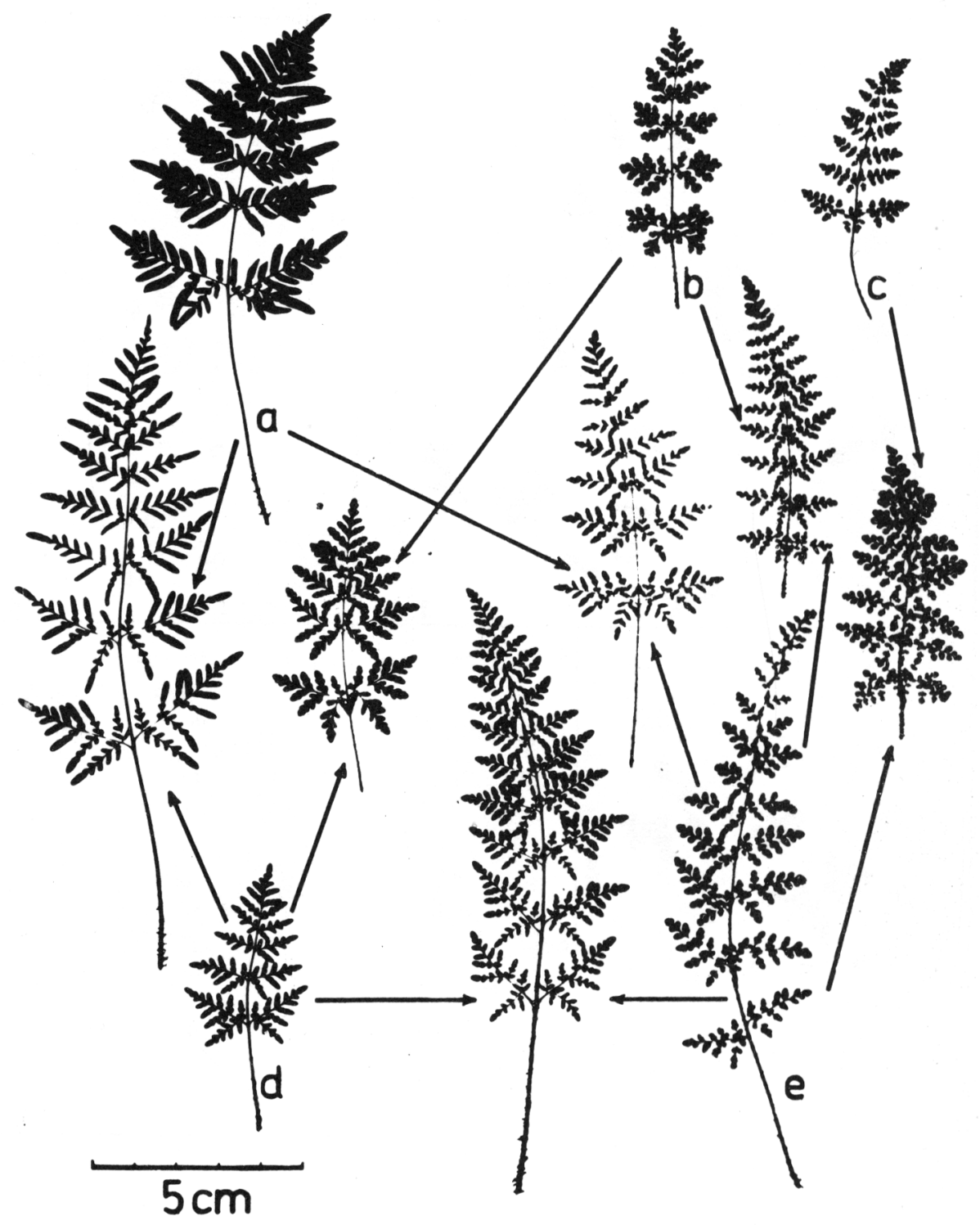

Fig. 8.- Silhouettes of fronds from cultivated plants of five species and six of their experimental hybrids, reduced. $a=$ C. pulchella (TR-1958); b = C. maderensis $(\mathrm{TR}-2030) ; \mathrm{c}=\mathrm{C}$. persica (TR-2322); $d=C$. guanchica $(T R-1915) ; e=C$. pteridioides (TR-1468). a x d (1958 x 1915); d x b (1915 x 2030); a x e (1468 x 1958); b x e (2030 x 1601); c x e (2310 x 1601); $d \times e(1956 \times 1600)$. 
Relations and Evolution in Cheilanthes

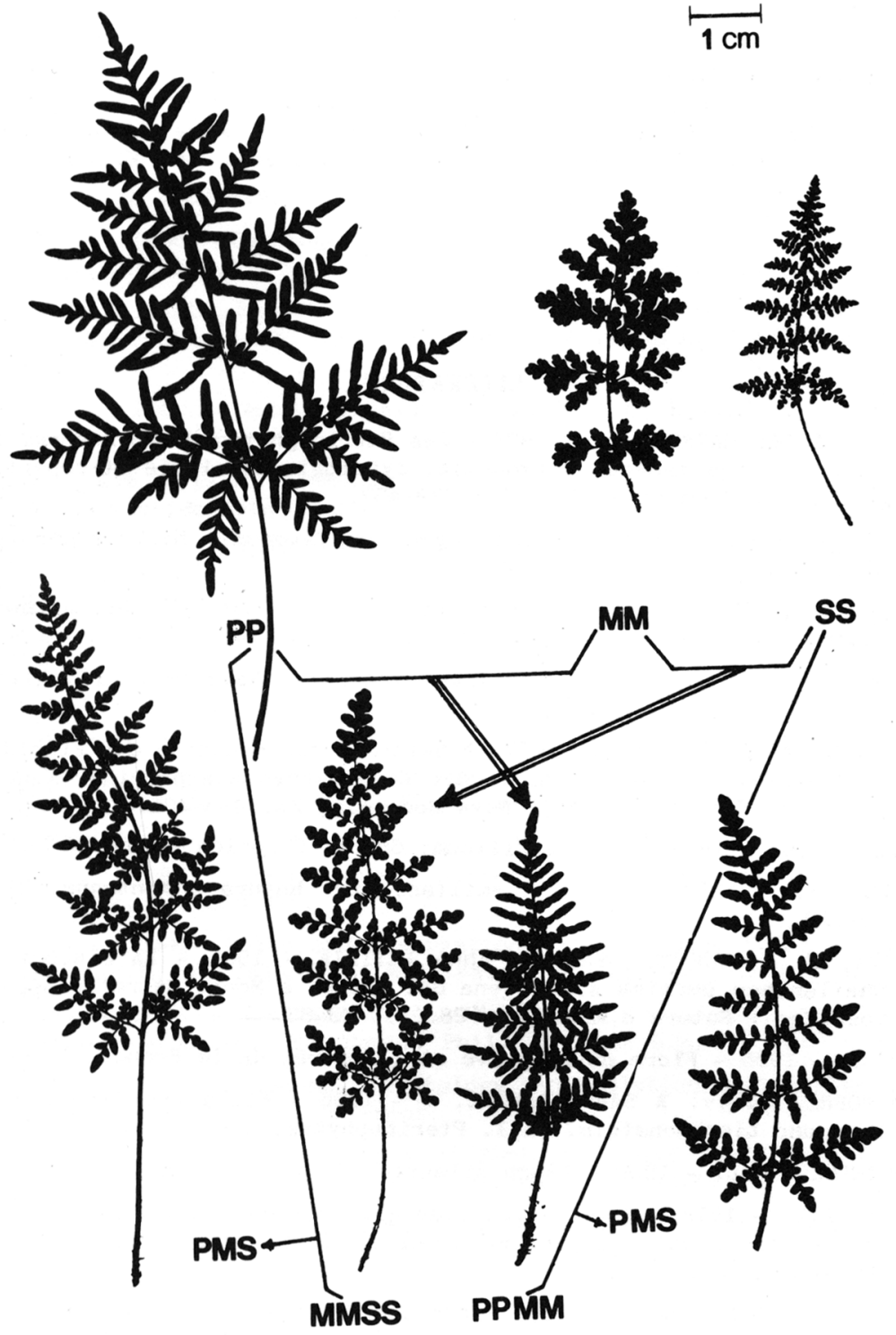

Fig. 9.- Silhouettes of fronds from cultivated plants of three diploid and two derived allotetraploid species: Ch. pulchella $=\mathrm{PP}(\mathrm{TR}-1958) ;$ Ch. maderensis $=\mathrm{MM}(\mathrm{TR}-2030) ; \mathrm{Ch}$. persica = SS (TR-2322); Ch. pteridioides = MMSS $(T R-1468)$ and Ch. guanchica $=$ PPMM (TR-1956) and the two triploid hybrids Ch. pteridioides $\mathrm{x}$ pulchella $=$ PMS $(\mathrm{TR}-1468 \times 1958)$ and Ch. guanchica $\mathrm{x}$ persica $=$ PMS $(\mathrm{TR}-1914 \times 2322)$. Both these hybrids (left and right side of lower line) made from different parents contain nevertheless the same three genome (PMS) and therefore show the same morphology. 


\section{ACKNOWLEDGEMENTS}

We wish to thank the following friends and colleaguesfor their help in preparing the manuscript, correction, valuable literature and plants: F. Badré (Paris), R. Deschatres (Bellerive), Dr. Mary Gibby (London), Prof. K.U. Kramer (Zürich), Dr. E. Nardi (Firenze), Dr. K. and Mrs. H. Rasbach (Glottertal).

\section{LITERATURE}

BADRE, F. \& DESCHATRES, R. - 1979 - Les Ptéridophytes de la France, liste commentée des espèces (taxonomie, cytologie, écologie et répartition générale). Candollea, 34: (2): 379-457.

BENL, G. - 1966a - Weitere Bemerkungen zur Taxonomie Kanarischer Farne. Mitt. Bot. München, VI : 33-45.

BENL, G. - 1966b - Ein fertiler Farnbastard der Gattung Cheilanthes aus Makaronesien. Nova Hedwigia, XII $(1,2)$ : 145-148 \& tab. 27-28.

BENL, G. - 1967 - Die Farne der Insel Tenerife. Nova Hedwigia, XIV: 69105.

BENL, G. \& SVENTENIUS, E.R. - 1970 - Beiträge zur Kenntnis der Pteridophyten-Vegetation und -Flora in der Kanarischen Westprovinz (Tenerife, La Palma, Gomera, Hierro), Nova Hedwigia, XX: 413-462.

COPELAND, E.B. - 1947 - Genera Filicum: 65-66, Chronica Botanica Co. U.S.A. CORBETTA, F. - 1980 - Le Felci emiliane etc. Natura e Montagna, 27 (3): 95-110.

CORBETTA, F. \& ZANOTTI CENSONI; ANNA LETIZIA - 1981 - La riscoperta di Cheilanthes persica sulla Vena del Gesso, a Monte Mauro(Preappennino faentino). Nature e Montagna, 28 (1): 83-88.

COSTE, H. - 1906 - Flore descriptive et illustrée de la France. I. Paris.

DALLA TORRE, K.G.v. \& SARNTHEIM, L. v - 1906 - Flora von Tirol, Vorarlberg und hiechtenstein. VI.1. Pteridophytae. Innsbruck.

DESFONTAINES, R.L. - 1800 - Flora Atlantica 2: 400, t. 256. Parisiis.

DESVAUX, A.V. - 1813 - Observations sur quelques nouveaux genres de fougères et sur plusieurs espècesnouvelles de la même famille. 2. Journ. de Bot. appl., 3: 92.

DOMIN, K. - 1913 - Beiträge zur Flora und Pflanzengeographie Australiens. 1: Pteridophyta (Prodromus einer Farnflora Queenslands). Bibl. Bot. 85.

DOMIN, K. - 1915 - Beiträge zur Flora und Pflanzengeographie Australiens, I. Teil 1. u. 2. Abt. Pteridophyta, Gymnospermae, Monocotyledoneae. Bibliotheca Botanica. Heft 85-I: 133-146.

FABERGE, A.C. - 1945 - Snail stomach cytase, a new reagent for plant cytology. Stain Technology, 20: 1-4.

FIORI, A. - 1923 - Nova Flora Analitica d'Italia I. Firenze (1923-1929).

FIORI, A. - 1943 - Flora Italica Cryptogama V. Pteridophyta. Firenze.

FRANCO, J. DO AMARAL - 1971 - Nova Flora de Portugal (Continente e Açores) Lisboa. 
FRITSCH, K. - 1897 - Excursionsflora für Oesterreich. Wien.

FUCHS, H.P. - 1961 - The genus Cheilanthes Swartz and its European species, Brit. Fern Gaz., (n.s.) 9 (2): 38-48.

GREUTER, W. \& RECHINGER, K.H. - 1967 - Flora der Insel Kythera, Boissiera, 13: 5-206.

GUINOCHET, H. \& VILMORIN, R. DE - 1973 - Flore de France I, Paris.

JANCHEN, E. - 1956 - Catalogus Florae Austriae. Wien, and 1963 Ergänzungsheft 1; 1964 Ergänzungsheft 2; and 1966 Ergänzungsheft 3.

JERMY, A.C. \& FUCHS, H.P. - 1964 - In Tutin, T.G. Heywood, V.H., Burgos, N.A. Valentine, D.N. Walters, S.M. \& Webb, D.A. (ed.) Flora Europaea, 1: 10 .

KUNKEL, G. - 1969 - Notas misceláneas. Cuad. Bot. Canar., 5: 45-51. Las Palmas .

LOVE, A., LOVE \& PICHI SERMOLLI, R.E.G. - 1977 - Cytotaxonomical Atlas of the Pteridophyta. Vaduz.

LOVIS, J.D. - 1968 - Fern hybridists and fern hybridizing II. Fern hybridizing at the University of Leeds. Brit. Fern Gaz., 10: 1-8.

LOVIS, J.D. - 1973 - A biosystematic approach to phylogenetic problems and its application to the Aspleniaceae In A.C. Jermy, J.A. Crabbe and B.A. Thomas (ed.) "The Phylogeny and Classification of the Ferns". Bot. J. Linn. Soc., 67, Suppl. 1: 210-227. Acad. Press, London-New York.

LOVIS, J.D. - 1975 - In C.A. Stace (ed.) "Hybridization and the Flora of the British Isles": 106-112. Acad. Press, London-New York-San Francisco.

LOVIS, J.D. - 1977 - Evolutionary patterns and processes in ferns. Adv. Bot. Res., 4: 229-415.

LOWE, R.T. - 1834 - Notes and observations on the above "List of Plants" observed in the Islands of Madeira. Journ. of Bot., I: 26.

LOWE, R.T. - 1838 - Novitiae Florae Maderensis: or Notes and Gleanings of Maderean Botany. Tr. Cambr. Phil. Soc., 6: 528.

MANTON, I. - 1950 - Problems of Cytology and Evolution in the Pteridophyta. Cambridge University Press.

MAXON, W.R. - 1926 - Pteridophyta of Porto Rico and the Virgin Islands. Sci. Surv. Porto Rico and Virgin Islands, 6: 373-521.

METTEnIUS, G. - 1859 - Uber einige Farngattungen, V. Cheilanthes. Abh. Senckenb. Naturforsch. Ges. Frankfurt, 3: 47-99.

MICKEL, J.T. - 1979 - The fern genus Cheilanthes in continental United States. Phytologia, 41: 431-477.

MUELleR, F.v. - 1866 - Fragmenta Phytographiae Australiae, 5: 123.

NARDI, E., RASBACH, H. \& REICHSTEIN, T. - 1978 - Identification of "Cheilanthes fragrans" var. "gennarii" Fiori with "C. guanchica" Bolle and remarks on related taxa. Webbia, 33 (1): 1-18.

NARDI, E., RASBACH, H. \& REICHSTEIN, T. - 1979 - "Cheilanthes tinaei" Tod., an earlier name for "C, corsica" Reichstein et Vida and related species in Sicily. Webbia, 33 (2): 449-456.

PICHI SERMOLLI, R.E.G. - 1977 - Tentamen Pteridophytorum genera in taxonomicum ordinem redigende. Webbia, 31: 313-512.

POIRET, J.L.M. - 1816 - Encyclopédie méthodique. Botanique. Suppl., 4: 110 . 
RASBACH, H., RASBACH, K. \& REICHSTEIN, T. - 1977 - Cheilanthes guanchica Bolle in Europe. Ber. Deutsch. Bot. Ges., 90: 527-530.

RASBACH, H., RASBACH, K. \& REICHSTEIN, R. - 1982 - Cheilanthes tinaei Tod. in Madeira and Tenerife; C.guanchica in Madeira. Willdenowia 12:77-80.

RASBACH, H. \& REICHSTEIN, T. - 1982 - Four natural hybrids of Cheilanthes. Webbia 35 (2): 261-273.

ROSSI, G. - 1981 - Dove ho ritrovato Cheilanthes persica. Natura e Montagna, 28: (1): 89-92.

ROY, S.K. \& MANTON, I. - 1965 - A new base number for the genus Lygodium New Phytologist, 64: 286-292.

SAENZ DE RIVAS, C. \& RIVAS-MARTINEZ, S. - 1979 - Revisión del género Cheilanthes (Sinopteridaceae) in España. Lagascalia, 8 (2): 215-241.

SOTA, E.R. DE LA - 1977 - Pteridophytas in Cabrera, A.L. (ed.) Flora de la Provincia de Jujuy República Argentina Parte II. Colección Científica del INTA-Tomo XIII, Buenos Aires.

SWARTZ, O. - 1806 - Synopsis Filicum 5, 126.

TRYON, R. - 1956 - A revision of the American species of Notholaena. Contr. Gray Herb. Harvard Univ. CLXXIX. Cambridge, Mass. U.S.A.

VASCONCELlos, J. DE CARVALHO E - 1968 - Pteridofitas de Portugal Continental e Ilhas adjacentes. Lisboa.

VIDA, G., PAGE, C.N., WALKER, T.G. \& REICHSTEIN, T. - 1970 - Zytologie der Farn-Gattung Cheilanthes in Europa und auf den Kanarischen Inseln. Verh. Schweiz. Naturforsch. Ges., 150: 149-150.

VIDA, G., PAGE, C.N., WALKER, T.G. \& REICHSTEIN, T. - 1971 - Cytologie der Farn-Gattung Cheilanthes in Europa und auf den Canarischen Inseln. Bauhinia, 4: 223-253.

VIDA, G., PAGE, C.N., WALKER, T.G. \& REICHSTEIN, T. - 1972 - Cytology of the Fern Genus Cheilanthes in Europe and in the Canary Islands. Symp. Biol. Hung. Budapest, 12: 103-104.

WAGNER, W.H. - 1954 - Reticulate evolution in the Appalachian Aspleniums. Evolution, 8: 103-118.

WALKER, T.G. - 1979 - The Cytogenetics of Ferns. In A.F. Dyer (ed.) The Experimental biology of Ferns. Acad. Press, London- New York-San Francisco.

WILLKOMM, M. \& LANGE, J. - 1870 - Prodromus Florae Hispanicae I. Stuttgartiae.

Comunicación presentada a la Reunión

Internacional de Pteridología (Algeciras, 1980)

Dirección de los autores:

G. VIDA \& A. MAJOR, Dept. of Genetics, Eötvös Lorand University Muzeum krt. 4.a., H-1088 Budapest.

T. REICHSTEIN, Dept. of Organic Chemistry, University, 19 St. Johanns-Ring, CH-4056 Basel 